\title{
KEEFEKTIFAN TEKNIK STORY TELLING DALAM PEMBELAJARAN SASTRA
}

\author{
Rukayah dan Aziz Thaba \\ Pendidikan Guru Sekolah Dasar, FIP Universitas Negeri Makassar \\ rukayahunm@yahoo.co.id \\ Pendidikan Bahasa dan Sastra Indonesia, FKIP Universitas Muhammadiyah Makassar \\ Educational Research and Development Indonesia (ERDI) \\ azizthaba@yahoo.co.id
}

\begin{abstract}
Abstrak
Penelitian ini bertujuan untuk: (1) mendeskripsikan hasil pembelajaran sastra tanpa menggunakan teknik storytelling, (2) mendeskripsikan hasil pembelajaran sastra dengan menggunakan teknik storytelling, dan (3) untuk mengetahui efektivitas model storytelling dalam pembelajaran sastra.

Hasil penilaian menunjukkan bahwa (1) pembelajaran tanpa menggunakan teknik storytelling dalam pembelajaran sastra tidak mencapai ketuntasan, (2) pembelajaran sastra dengan menerapkan teknik storytelling telah mencapai ketuntasan, dan (3) adanya keefektifan penggunaan teknik storytelling siswa kelas VIII SMP Negeri 2 Sungguminasa. Hal ini membuktikan bahwa dengan menggunakan teknik storytelling dapat meningkatkan pembelajaran siswa dalam pembelajaran sastra yang dilihat dari nilai rata-rata kelas kontrol, yaitu 75.3, sedangkan kelas eksperimen memeroleh nilai rata-rata, yaitu 85.9.

Di samping itu data hasil observasi setiap pertemuan menunjukkan adanya perubahan sikap siswa kearah yang lebih positif, baik dari segi sikap belajar dan keaktifannya. Dari hasil analisis tersebut dapat disimpulkan bahwa penerapan teknik storytelling efektif digunakan dalam pembelajaran sastra.
\end{abstract}

Kata Kunci : Keefektifan, storytelling, sastra.

This study aims to: (1) describe the results of literary learning without using storytelling techniques, (2) to describe the results of literary learning using storytelling techniques, and (3) to determine the effectiveness of the storytelling model in literary learning. The results of the assessment show that (1) learning without using storytelling technique in literary learning does not reach completeness, (2) the learning of literature by applying storytelling technique has reached completeness, and (3) the effectiveness of storytelling technique of VIII students of SMP Negeri 2 Sungguminasa. This proves that using storytelling technique can improve student's learning in literature learning which is seen from the average value of control class, that is 75.3, while the experimental class gets the average value, that is 85.9. In addition, the observation data of each meeting indicates a change in student attitudes towards a more positive, both in terms of learning attitudes and activities. From the results of the analysis can be concluded that the application of effective storytelling techniques used in learning literature.

Keywords: Effectiveness, storytelling, literature 


\section{A. PENDAHULUAN}

Bahasa merupakan alat yang paling penting dalam berkomunikasi. Komunikasi terjadi setiap saat ketika seseorang melakukan aktivitas, baik komunikasi langsung maupun tidak langsung. Oleh karena itu, seseorang perlu mempelajari bahasa dengan tujuan yang beraneka ragam, misalnya untuk mencari ilmu pengetahuan, untuk meningkatkan kemampuan atau keterampilan berbahasa dan sebagainya (Zabadi, 2014).

Pada tahun pelajaran 2014/2015, pemerintah mengambil kebijakan untuk mengimplementasikan kurikulum 2013 (K13) pada jenjang pendidikan SD, SMP, dan SMA sederajat di tanah air. Kurikulum ini bertujuan mengubah pola dan muatan materi pembelajaran di kelas. Salah satu pola dan materi pembelajaran itu adalah muatan sastra yang terangkum dalam mata pelajaran bahasa Indonesia (Ampera, 2010).

Pada kurikulum 2013 mata pelajaran untuk siswa kelas VIII, pembelajaran menulis terdapat dalam KI 4 pada Kompetensi Dasar 4.2 menyusun teks cerita moral/fabel, ulasan, diskusi, cerita prosedur, dan cerita biografi sesuai dengan karakteristik teks yang akan dibuat baik secara lisan maupun tulisan. Salah satu yang menjadi fokus dalam penelitian eksperimen ini ialah mengenai kemampuan siswa dalam menyusun dan berbicara mengenai teks cerita moral/fabel. Kurikulum 2013 ini lebih mendekatkan siswa pada lingkungan sekitarnya. Hal ini pula yang menjadikan siswa dapat cepat memahami pelajaran dan memahami nilai-nilai moral yang terdapat di dalam karya sastra sebagai basis pendidikan karakter (Yusuf, 2005). Belajar (sastra) bukan untuk kepentingan jangka pendek tetapi lebih kepada kepentingan masa depan (Utami, dkk. 1988)

Kemunculan dongeng binatang (fabel) di Indonesia tidak lepas dari sejarah perkembangan Indonesia dimasa lampau, dimana agama Hindu-Budha menjadi agama mayoritas waktu itu. Sugiarto (2012) berpendapat bahwa, "Fabel awalnya muncul di India, pengarang fabel menggunakan tokoh binatang sebagai pengganti manusia, atas dasar kepercayaan bahwa binatang bersaudara dengan manusia. Menurut Kamus Besar Bahasa Indonesia (KBBI, 2008), "Fabel adalah cerita yang menggambarkan watak dan budi manusia yang perilakunya diperankan oleh binatang."

Kusmiadi (2008) menjelaskan bahwa Storytelling adalah cara yang dilakukan untuk menyampaikan suatu cerita kepada para penyimak, baik dalam bentuk kata-kata, gambar, foto, maupun suara. Storytelling juga merupakan teknik atau kemampuan untuk menceritakan sebuah kisah, pengaturan adegan, event, dan juga dialog (Sya'adatun, 2013). Teknik ini bermanfaat melatih kemampuan mendengar secara menyenangkan (Aliyah, 2011). Untuk menyampaikan storytelling harus mempunyai kemampuan public speacking yang baik, memahami karakter pendengar, meniru suara-suara, pintar mengatur nada dan intonasi serta keterampilan menggunakan alat bantu. Dikatakan berhasil menggunakan teknik Storytelling jika pendengar mampu menangkap jalan cerita serta merasa terhibur. Demikian dasar terampil dalam berbicara yang menjadi acuan teknik storytelling (Tarigan, 2008).

SMP Negeri 2 Sungguminasa telah menerapkan kurikulum 2013 dalam proses pembelajarannya. Proses 
pemebelajarannya sudah baik akan tetapi masih banyak siswa yang terkadang tidak memperhatikan pelajaran dan terkesan jenuh. Hal ini terkadang disebabkan karena tehnik yang digunakan guru tidak dipahami oleh siswa. Karena seperti yang kita ketahui terkadang guru hanya menyampaikan materi tanpa melibatkan siswa. Hal itulah terkadang membuat siswa merasa jenuh mengikuti pelajaran yang diajarkan. Terlebih lagi jika materi yang disampaikan oleh guru tidak dibawakan dengan teknik yang tepat.

Sehubung dengan masalah di atas, maka dalam penelitian ini diujicobakan teknik pembelajaran yang dapat melatih keberanian siswa untuk berbicara dan tampil di hadapan banyak orang berawal dari tampil di hadapan siswasiswa lainnya. Teknik tersebut adalah teknik storytelling. Teknik ini mampu membangun rasa percaya diri siswa saat berada di depan umum. Oleh karena itu, penulis termotivasi untuk meneliti keefektifan teknik storytelling dalam bentuk studi eksperimentasi.

\section{B. METODE PENELITIAN}

Penelitian ini adalah penelitian eksperimen. Eksperimen yang digunakan adalah quasi experimental atau ekperimen semu. Dalam penelitian ini terdapat dua kelompok subjek yakni kelompok eksperimen dan kelompok pembanding (kelompok kontrol). Penelitian ini dilaksanakan di SMP Negeri 2 Sungguminasa yang beralamat di Jl. Andi Mallombasang No.1 Sungguminasa Kecamatan Somba Opu Kabupaten Gowa. Populasi penelitian ini adalah siswa kelas VIII dengan jumlah siswa 72 orang yang terbagi dalam dua kelas. Dalam satu kelas terdapat 36 siswa. Keseluruhan populasi tersebut dijadikan sebagai sampel sehingga penelitian ini juga disebut penelitian populasi (Sugiyono, 2010). Teknik yang digunakan dalam pengumpulan data pada penelitian ini adalah teknik tes dan nontes (observasi). Langkah-langkah menganalisis data yaitu (a) membuat tabulasi skor siswa, (b) menghitung nilai kemampuan tiap siswa, (c) uji persyaratan analisis meliputi uji normalitas dan uji hipotesis. Uji normalitas ini dilakukan untuk mengetahui sampel yang diambil berasal dari populasi yang berdistribusi normal atau tidak, (d) menentukan perbandingan hasil protest dan protest kemampuan siswa sebagai tolak ukur keefektifan teknik storytelling.

\section{HASIL PENELITIAN}

\section{Hasil Penelitian Kelas Eksperimen}

Pada pertemuan pertama dilakukan pretest, untuk mengetahui sampai mana kemampuan siswa dalam pembelajaran fabel. Pretest yang dilakukan disini yaitu lisan. Siswa diperhadapkan dengan sebuah gambar kemudian meceritakan kembali isi gambar yang dilihatnya sesuai dengan struktur teks cerita fabel. Hasil yang diperoleh dari pretest ini hanya ada 3 orang siswa yang mampu mencapai nilai standar kelulusan yaitu 80 dan yang tidak tuntas ada 33 orang siswa. Kemudian dilaksanakan pembelajaran dengan menggunakan teknik storytelling sesuai dengan langkahlangkah teknik pembelajaran tersebut. Kemudian dipertemuan selanjutnya kembali dilaksanakan posttest untuk mengetahui hasil belajar siswa setelah menggunakan teknik storytelling. Dari hasil posttes diperoleh 35 siswa yang tuntas dan 1 siswa yang tidak tuntas.

Sampel nilai tertinggi yang diperoleh siswa yaitu 95 yang diperoleh 
4 orang $(11.1 \%)$, sampel yang mendapat nilai 93 berjumlah 2 orang $(5.5 \%)$, sampel yang mendapat nilai 90 berjumlah 5 orang (13.8\%), sampel yang mendapat nilai 89 berjumlah 3 orang $(8.9 \%)$, sampel yang mendapat nilai 88 berjumlah 4 orang (11.1\%), sampel yang mendapat nilai 86 berjumlah 2 orang $(5.5 \%)$, sampel yang mendapat nilai 85 berjumlah 5 orang (13.8\%), sampel yang mendapat nilai 82 berjumlah 2 orang (5.5\%), sampel yang mendapat nilai 80 berjumlah 8 orang (22.2\%), dan sampel yang mendapat nilai 65 berjumlah 1 orang (2.7\%). Jadi total jumlah frekuensinya yaitu 36 dan presentaseya $100 \%$.

Jika ilai interval siswa 90-100 maka tingkat hasil belajar siswa sangat tinggi, sedangkan jika nilai intervalnya 80-89 maka tingkat hasil belajar siswa tergolong tinggi, jika 70-79 tergolong sedang, 40-69 tergolog redah, dan 00-39 tergolong sangat rendah. Maka nilai rata-rata kompetensi pembelajaran fabel siswa kelas eksperimen dikategorikan tinggi. Hal ini terlihat pada tabel 4.2 di atas yang menunjukkan bahwa nilai rata-rata siswa yaitu 85.9 berada pada rentang nilai 80-89 (kategori tinggi).

\section{Hasil Penelitian Kelas Eksperimen}

Hasil penelitian kelas kontrol dengan 36 siswa yang dianalisis diperoleh gambaran, yaitu tidaka ada siswa yang memperoleh nilai 100 sebagai nilai maksimal. Nilai tertinggi yaitu 88 yang diperoleh 1 orang siswa dan nilai terendah yang diperoleh oleh 2 orang siswa yaitu 60 .

Sampel nilai tertinggi yang diperoleh siswa yaitu 88 yang diperoleh 1 orang $(2.7 \%)$, sampel yang mendapat nilai 85 berjumlah 3 orang $(8.3 \%)$, sampel yang mendapat nilai 80 berjumlah 5 orang (13.8\%), sampel yang mendapat nilai 79 berjumlah 4 orang $(11.1 \%)$, sampel yang mendapat nilai 78 berjumlah 4 orang $(11.1 \%)$, sampel yang mendapat nilai 76 berjumlah 1 orang $(2.7 \%)$, sampel yang mendapat nilai 75 berjumlah 3 orang (8.3\%), sampel yang mendapat nilai 74 berjumlah 4 orang $(11.1 \%)$, sampel yang mendapat nilai 70 berjumlah 8 orang $(22.2 \%)$, sampel yang mendapat nilai 65 berjumlah 1 orang $(2.7 \%)$, dan sampel yang mendapat nilai 60 berjumlah 2 orang Jadi total jumlah frekuensinya yaitu 36 dan presentaseya $100 \%$. jika nilai interval siswa 90-100 maka tingkat hasil belajar siswa sangat tinggi, sedangkan jika nilai intervalnya 80-89 maka tingkat hasil belajar siswa tergolong tinggi, jika 70-79 tergolong sedang, 40-69 tergolog redah, dan 00-39 tergolong sangat rendah. Maka nilai rata-rata kompetensi pembelajaran fabel siswa kelas eksperimen dikategorikan tinggi. Hal ini terlihat pada tabel 4.4 yang menunjukkan bahwa nilai rata-rata siswa yaitu 75,3 berada pada rentang nilai 70-79 (Sedang).

\section{Uji Persyaratan Data}

Pengujian data statistik ini dengan bantuan SPSS versi 16, hasil analisis kelas kontrol ditolak dan hasil analisis kelas eksperimen diterima, jadi penerapan teknik storytelling efektif diterapkan pada pembelajaran fabel pada siswa kelas VIII SMP Negeri 2 Sungguminasa.

Penelitian ini dilakukan pada dua kelas yaitu kelas VIII.2 sebagai kelas eksperimen, dan kelas VIII.1 sebagai kelas kontrol. Pada kelas eksperimen dilakukan pretest pada pertemuan pertama untuk mengetahui sampai dimana pemahaman siswa terhadap pembelajaran fabel. Kemudian setelah dilakukan pretest, pada pertemuan 
selanjutnya peneliti mulai melakukan pembelajaran dengan teknik storytelling. Awalnya masih banyak siswa yang sibuk dengan urusan masing-masing dan tidak memperhatikan pelajaran, tetapi dengan menggunakan alat peraga siswa mulai tertarik megikuti proses pembelajaran. Setelah itu, dilakukan posttest kembali untuk mengetahui pemahaman siswa.

Kemudian pada kelas kontrol, juga dilakukan posttest pada pertemuan pertama untuk mengetahui pemahaman siswa, kemudian pada pertemua selanjutnya dilakukan proses pembelajaran seperti biasanya, dan di kelas ini siswa banyak yang tidak memperhatikan pelajaran dan sibuk dengan urusan masing-masing, berjalan kiri kanan dengan alasan tidak adanya buku paket. Kemudian kembali dilakukan posttest untuk mengetahui kemampuan siswa.

Pada bagian ini diuraikan temuan yang diperoleh dari hasil analisis data penelitian. Dari hasil analisis data kelas eksperimen, rata-rata hasil tes kelas eksperimen adalah 85.9 sedangkan kelas kontrol adalah 75,3. Jadi, kelompok kelas yang menggunakan teknik storytelling mempunyai kompetensi berbicara lebih tinggi dari pada kelompok yang tidak menerapkan teknik storytelling pada pembelajaran fabel SMP Negeri 2 Sungguminasa.

Dari hasil perbandingan rata-rata hasil tes siswa antara kelas eksperimen dengan kelas kontrol dengan menggunakan rumus uji $t$ dapat diketahui bahwa nilai $t_{\text {hitung }}$ yang diperoleh sebesar 6.118. hasil penelitian ini mengungkapkan bahwa pembelajaran fabel kelas eksperimen yang menerapkan teknik storytelling lebih tinggi dari pada kelas kontrol yang tidak menerapkan tekik storytelling.
Oleh karena $t_{\text {hitung lebih besar }}$ hipotesis nol $\left(\mathrm{H}_{0}\right)$ ditolak dan hipotesis alternative $\left(\mathrm{H}_{1}\right)$ diterima. Hal ini berarti bahwa penerapan teknik storytelling efektif diterapkan dalam pembelajaran fabel siswa kelas VIII SMP Negeri 2 Sungguminasa.

Keberhasilan penerapan storytelling dalam pembelajaran fabel memberikan informasi bahwa penerapan storytelling sangat tepat digunakan dalam upaya meningkatkan prestasi dan membangun kepercayaandiri pada siswa untuk lebih aktif dalam pembelajaran. Oleh karena itu, dalam setiap pembelajaran di sekolah seyogyanya guru lebih kreatif dalam melihat perkembangan siswa dalam setiap pembelajaran agar siswa lebih nyaman dalam menerima setiap pelajaran yang diberikan oleh guru. Penerapan teknik storytelling di sekolah membuat para siswa lebih cerdas melihat realita yang ada dalam kehidupan sehari-hari melalui kegiatan berbicara yang mampu mengasah kemampuan siswa untuk mengolah kata-kata menjadi sebuah kalimat terlebih mampu menanamkan rasa percayadiri pada siswa. Setelah dilakukan pretest dan posttest diketahui jika terjadi peningkatan hasil belajar siswa. Hal itu menunjukkan bahwa siswa memiliki perhatian yang cukup besar dalam pembelajaran fabel melalui teknik storytelling.

\section{SIMPULAN}

Berdasarkan uraian pada bab IV di atas, maka kesimpulan yang dapat diperoleh adalah teknik storytelling efektif digunakan dalam pembelajaran fabel pada kelas VIII SMP Negeri 2 Sungguminasa. Hasil analisis data yang diperoleh setelah melakukan pretest dan 
posttest pada kelas eksperimen hasil pretest 69,1 dan posttest 84,6. Sedangkan pada kelas kontrol, hasil analisis data pretest 68,1 dan posttest 75,3 . Untuk aktivitas guru juga telah dilaksanakan dengan baik, seperti memberi materi dengan menggunakan alat peraga dan mengamati kegiatan siswa.

Hal ini dapat dilihat dari ketuntasan rata-rata klasikal antara

\section{DAFTAR PUSTAKA}

Aliyah, Siti. 2011. Pengaruh Metode Storytelling dengan Media Panggung Boneka Terhadap Peningkatan Kemampuan Menyimak dan Berbicara Anak Usia Dini. Majalengka: Universitas Pendidikan Indonesia.

Ampera, Taufik. 2010. Pengajaran Sastra. Bandung: Widya Padjajaran.

Departemen Pendidikan Nasional. 2008. Kamus Besar Bahasa Indonesia. Jakarta: PT Gramedia Pustaka Utama.

Husrin. 2014. Efektifitas Model Educations Games dalam Pembelajaran Menulis Puisi Siswa Kelas XI SMA Muhammadiyah 6 Makassar. Makassar: Universitas Muhammadiyah Makassar.

Kusmiadi. 2008. Strategi Pembelajaran PAUD Melalui Metode Storytelling. Surabaya: UIN Sunan Ampel.

Radhika, Fikar. 2014. Keefektifan Penggunaan Model Example NonExample dalam Pembelajaran penggunaan teknik storytelling yaitu 84,6 dan tanpa menggunakan teknik storytelling yaitu 75,3. Pada pretest kelas kontrol siswa yang tuntas ada 2 orang, posttest ada 9 orang yang tuntas. Sedangkan pada kelas eksperimen, siswa yang tuntas pada prestest ada 3 orang dan posttest ada 35 siswa yang tuntas.

Menulis Teks Fabel Pada Siswa Kelas VIII SMP Negeri 6 Magelang. Yogyakarta: Universitas Negeri Yogyakarta.

Sugiarto, Ryan. 2012. Republik Rimba. Bandung: Indie Book Corner.

Sya'adatun, Niswah. 2013. Pengaruh Metode Storytelling Terhadap Pengembangan Minat Baca dan Bahasa Anak Kelompok B di TK Tunas Bangsa Pati. Surakarta: Universitas Muhammadiyah Surakarta.

Tarigan. 2008. Berbicara Sebagai Suatu Keterampilan Berbahasa. Bandung: Angkasa.

Utami, Munandar dkk. 1988. Kreativitas sepanjang masa. Jakarta: Pustaka Sinar Harapan.

Yusuf, Syamsu LN. 2005. Psikologi Perkembangan Anak dan Remaja. Bandung: Rosdakarya.

Zabadi, Fairul \& Sutejo. 2014. Bahasa Indonesia Wahana Pengetahuan. Jakarta: Kementerian Pendidikan dan Kebudayaan 